\title{
Neurodiversity as a teaching tool for educational inclusion.
}

La neurodiversidad como herramienta docente para una inclusión educativa.

\author{
Patricia Amezcua Aguilar \\ Universidad de Jaén (España) \\ patricia.ilse@hotmail.com \\ Carmen Flores Melero \\ Universidad de Jaén (España) \\ carmenfloresmelero17@gmail.com \\ Cristina Marín Perabá \\ Universidad de Jaén (España) \\ cristinamarinp97@gmail.com
}

Fecha recepción: 14/10/2019

Páginas 88-97

Fecha aceptación: 25/12/2019

\begin{abstract}
.
Great teachers are characterized by the fact that they never stop learning, that is why terms such as the term "pluri-disability" must be in the vocabulary of any of the teachers in our country's classrooms, the meaning of it, the characteristics it encompasses and those it does not, in order to include this type of student satisfactorily in the socio-academic field. In addition, teacher learning must be based on the inclusion of students, which is why sign language training is required for the complete well-being of students.

Different studies in neuroscience show that there are no two equal brains, that is, each person presents a unique way of perceiving and analyzing information that contributes to how learning occurs. This has given way to the development of the paradigm called Universal Design for Learning, which makes it possible to create a curriculum accessible to all, favouring inclusion and equal opportunities.
\end{abstract}

Keywords: multy disability; neurodiversity; auditorydisability; universal design for learning

\section{Resumen.}

Los grandes docentes se caracterizan por no dejar jamás de aprender, es por esto que términos como el de "pluridiscapacidad" ha de estar en el vocabulario de cualquiera de los maestros y maestras de las aulas de nuestro país, el significado del mismo, las características que abarca y las que no, para poder incluir a este tipo de alumnado de manera satisfactoria en el ámbito socio-académico. Además, el aprendizaje del docente tiene que estar basado en la búsqueda de inclusión de su 
alumnado, es por ello que se requiere de formación en lengua de signos para un completo bienestar del alumnado.

Diferentes estudios en neurociencia muestran que no existen dos cerebros iguales, es decir, cada persona presenta una forma única de percibir y analizar la información que contribuye a cómo se produce el aprendizaje. Esto ha dado paso al desarrollo del paradigma denominado Diseño Universal para el Aprendizaje, que permite crear un currículo accesible para todos, favoreciendo la inclusión y la igualdad de oportunidades.

Palabras clave: pluridiscapacidad, neurodiversidad, discapacidad auditiva; diseño universal para el aprendizaje

\section{1.-Introduction.}

Any person who dedicates professionally to the field of education, has to have an inclusive basis acquired, therefore, this bibliographic search has been carried out, to raise awareness and involve teachers in the world of neurodiversity and therefore in the Neuroeducation, being aware of the main characteristics presented by students, addressing their intervention according to their abilities.

Thus, the latest research in neuroeducation brings us closer to the understanding of how learning occurs and through what mechanisms, showing us in this way how each individual perceives, analyzes and interacts with reality in a unique way.

This new knowledge has promoted the creation of the paradigm called Universal Design for Learning, which aims to design activities and / or learning addressing the diversity of students, ensuring inclusion and accessibility in equal opportunities.

In addition, focus on the importance of the concept of multi-disability as one of the most used but least known by education professionals.

More in depth, the appropriate inclusion of deaf people in the educational field is developed, from the point of view of the problem of poor teacher training in sign language.

\section{2.-Theoretical Framework.}

\section{1.-Multi-disability and neurodiversity.}

One of the affectations that we can find in our educational centers, more specifically in the TP classrooms, are people with multi-disabilities. Therefore, it is essential to know the term, as it is common to have this type of students in our classrooms, which are the aspects that affect people with multi-disabilities or not and which way is the most suitable for working with them.

Often, we try to label students, and there are those who are against this, however, the process of classifying students according to their characteristics has the mail objective of adapting and posing appropriate learning methodologies for their personal development. So, we are going to see the main features of a person with multiple disabilities, according to Soro - Camats, Basil y Rosell (2012), who in them 
book name "Pluridiscapacidad y contextos de intervención", explain that a person is affected with multiple disabilities due to motor disabilities, to a large extent severe, difficulty in language acquisition, which has a negative and direct impact on their communicative, comprehensive and expressive skills, both emotionally and emotionally. In addition, this type of student presents intellectual disability, giving greater or lesser degree, great memory difficulties, little awareness about the world, so all this leads to an emotional development of the person.

What is more, explains Soro - Camats, Basil y Rosell (2012), that they can speak of a person with multi-disabilities when there is severe and / or profound dysfunction in two or more areas of human development, the intellectual development must be affected, that is, the person must have intellectual disability to a greater or lesser degree.

The human brain is a muscle, and like any muscle differs from one person to another, it is Flórez (2016), who distinguished two types of brain formation from two different processes. The first is brain growth at the level of essential human behavior, which can be said is the animal base of every human being. On the other hand, the second process is that which establishes the personal development of the human species, referring to qualities, abilities, multiple intelligences or talents, etc.

The main force that gives brain networks their special property is invincible, constitutive and immutable, consolidating the person as unique, keeping intact the place of origin, personal essence, character or personality himself. In this sense, there isn't neurodiversity.

However, Flórez (2016) states: "How many neurons have been born in a particular individual?" "How many have taken their rightful place?" This is where regularity, individuality and diversity in human are combined. Only beginning to imagine the brain as unique to each person can we talk about neurodiversity.

In accordance with the above, we can understand how to reevaluate the characteristics that cause negative consequences on personal development. Thanks to Astorga (2012), we understand that the concept of neurodiversity gives us the ability to open wide horizons in the study of the human mind and interpretations about the different capacities of people.

In this way, the different investigations that have been carried out in the field of neuroscience, show that when we learn, the brain creates different neural networks (Pastor, 2012) that come into operation together and therefore it is necessary to attend to each one of them in order to ensure a correct didactic transposition.

- Recognition Network. It refers to the WHAT of the learning process, specializes in receiving and analyzing information. This neural network is activated by providing information in multiple modes of representation - auditory, visual, tactile. Depending on the individual patterns in the acquisition of student learning, a better collection of information will be facilitated by offering more 
options, being able to choose the most appropriate means of representation for each one of them and therefore learn significantly.

- $\quad$ Strategic network. It could be considered as the executive neural network, that is, the planning of HOW it occurs and the learning result is shown. The UDL give to the students the possibility of offering multiple forms of response, being able to elaborate and present their tasks in different media or formats - written, audiovisual, dramatized, etc.,allowing a freer expression, natural and adapted to their abilities, through the necessary supports.

- Affective network. It refers to the WHY of learning and is closely related to the motivation towards the task, which is responsible for the action and the implication for learning through participation. Equally, it is necessary to underline that this motivation and commitment are affected by many variables, such as personal interest in the task, past experiences, culture or the neurological functioning itself.

Following the line of thought of this author and through the different research in neuroeducation, we can understand that neural networks show a functioning and activation, it is different in each person, so that, an individual can present greater ease when processing the information depending on the senses used, which will follow different strategies for the planning or execution of a task using the means of production that best suits your personal characteristics, thus influencing motivation and involvement in a specific activity.

\section{2.-Universal Design for Learning.}

This new perspective of an inclusive nature, according to Pastor (2014), was born to refer to the design of products, environments and communication so that they are usable for all people, without adaptation or specialized design, regardless of their age, ability or condition in life (p. 2).

In this way, Universal Design has opened the way in the different areas of people's lives, being the first educational in the areas in which it has aroused the most interest, creating a new paradigm, still under construction, called Universal Design for Learning (UDL onwards) and that it is framed in the field of neuroscience, showing how people learn, perceive and analyze the reality, this information being very useful to be able to design learning and activities that attend to individual characteristics of learners, thus favoring access to Information on equal opportunities in the world, that is, how to design an activity so that it is accessible to all students as much as possible.

Center for Applied Special Technology (CAST) was the responsible to develop UDL, this criticizes that the academic curriculum is designed to serve a majority of students, but not all of them, understanding that there is a single form of generalized learning. All this causes a minority to be excluded in order to successfully achieve academic objectives, that is, students who have different learning characteristics. 
Therefore, the main objective is the creation of an educational community that accepts the diversity of students as another element of the curriculum, giving it the positive and enrichment value that it really supposes within the classroom.

Different authors such as McGuire, Scott and Shaw, 2006; Hitchcock and Stahl, 2003 state that "A curriculum planned under the principles of universal design is specifically designed to serve a diverse set of students with a wide range of sensory, motor, cognitive, affective and linguistic skills" (From Villoria, \& Fuentes, 2015. p. 2), so that its the need to make future adaptations dependent on the profile or characteristics of the students is minimized, providing flexibility in objectives, content, materials and evaluation.

\subsection{1.-UDL Curriculum.}

For the training of apprentices it is necessary to attend the main components of a UDL curriculum that, according to Pastor, Hípola, Serrano \&del Río, (2013) are interrelated and are:

- Objectives: they are focused on recognizing the variability of the students and differentiating between the learning objectives and the means necessary to acquire them.

- Methods: experts differentiate and use a multitude of methods in reference to the objective of teaching, so that they are flexible, varied and adjusted based on the systematic monitoring of the teaching process and student progress.

- Instructional materials: Variability and flexibility are the fundamental pillars in the design of activities within the UDL framework. Regarding the involvement and motivation towards the task, UDL materials provide us with different alternatives to achieve the goals, through various levels of support and challenge.

- Assessment: It focuses on keeping the focus of attention fixed on the objective of learning and not on the means necessary to reach it, using a variety of methods and materials to facilitate the knowledge and skills acquired, eliminating barriers that limit or prevent learning (p. 6-7).

\subsection{2.-UDL \& ICT.}

It is true that the traditional educational system is effective for part of the students, it is not for everyone as previously stated, because "each medium has inherent barriers that make it inaccessible for a student sector" (Pastor, 2014, p. 14).

It is the versatility of ICT that is an advantage over traditional teaching means, such as the textbook, which has a rigid structure and format and is not susceptible to adaptations, however, the digital medium provides great flexibility and immediacy due to the need for significant changes in its configuration with respect to traditional media (Rose and Meyer, 2002, cit. Pastor, Sánchez y del Río, 2014) due to its: 
1. Versatility; The information can be stored in multiple formats and can be combined with each other.

2. Transformation capacity; ICTs allow information to be transformed both in the way in which it is presented (volume, background-letter contrast, text size, etc.) and between different media, for example, the transformation of written text to digital audio.

3. Ability to mark; The digital media allow to modify the format of presentation of the information, highlighting, marking or even hiding certain information, depending on the individual characteristics of each student.

4. Ability to network; The existence of the cloud and the fact that knowledge is interconnected in the network with each other, facilitates autonomous learning and the ability to relate some knowledge to others, improving the transfer or extrapolation of acquired knowledge.

\subsection{3.-Principles, guidelines and verification points of the ULD.}

In order to design a curriculum within the DUA framework, it is necessary to address the different neural networks that activate learning. For this, the CAST defined a series of principles related to each of these networks, establishing the basis of the approach and being the means to apply to the curriculum. Below is a table in which they are collected in summary form:

\begin{tabular}{|l|l|l|}
\hline $\begin{array}{l}\text { Principle I.- Provide } \\
\text { multiple forms of } \\
\text { representation (recognition } \\
\text { network) }\end{array}$ & $\begin{array}{l}\text { Principle II.- Provide } \\
\text { multiple forms of action } \\
\text { and expression (strategic } \\
\text { network) }\end{array}$ & $\begin{array}{l}\text { Principle Ill.- Provide } \\
\text { multiple forms of } \\
\text { involvement (affective } \\
\text { network) }\end{array}$ \\
\hline $\begin{array}{l}\text { Guideline 1.- Provide different } \\
\text { options to perceive } \\
\text { information }\end{array}$ & $\begin{array}{l}\text { Guideline 4.- Provide multiple } \\
\text { physical means of action }\end{array}$ & $\begin{array}{l}\text { Guideline 7.- Provide options } \\
\text { to capture interest }\end{array}$ \\
\hline $\begin{array}{l}\text { Guideline 2.- Provide multiple } \\
\text { options for language and } \\
\text { symbols }\end{array}$ & $\begin{array}{l}\text { Guideline 5.- Provide multiple } \\
\text { forms of action and } \\
\text { expression }\end{array}$ & $\begin{array}{l}\text { Guideline 8.- Provide options } \\
\text { for self-regulation }\end{array}$ \\
\hline $\begin{array}{l}\text { Guideline 3.- Provide options } \\
\text { for understanding }\end{array}$ & $\begin{array}{l}\text { Guideline 6.- Provide options } \\
\text { for executive functions }\end{array}$ & \multicolumn{2}{|l}{} \\
\cline { 1 - 2 }
\end{tabular}

Table 1. Universal design for learning: Principles, guidelines and verification points.

Own elaboration based on Pastor, Sánchez and Zubillaga, 2014, p. 29-36.

Different technological advances and new knowledge within the field of neuroeducation provide us with evidence-based knowledge, which allows the 
development of more effective and inclusive methodologies, providing teachers with strategies and tools to offer quality education and equal opportunities

Therefore, the specific training of the teacher in neuroscience and neurodiversity is essential for these advances to become a reality in the school, creating a more just and supportive society, and therefore inclusive.

\section{3.-Teacher training in sign language.}

Functional diversity is present daily in schools, one of the most relevant, is the presence of students with hearing impairment in the classroom. For these students, the biggest problem they encounter in the centers is the usual exclusion to which they are subjected. This school exclusion can be worked with the elimination of physical, communicative, personal and curricular barriers, among others. It is of great importance that tools such as sign language be used in the classroom, fundamentally when there is the presence of hearing deficits in class, but for this the teaching staff must be previously trained according to the needs of the students.

A language is complex to learn when you do not have knowledge about it, that is why the Federación Mundial de Personas Sordas (2019) argues that sign language is just as complex to learn as any other, since it does not share syntactic structure with any other language. Not for this reason, this language is unimportant, but is increasingly necessary every day. The introduction of sign language in the classroom is unavoidable, but the lack of resources and the lack of training in teachers, is the problem that occurs most in the 21st century, and what converges in school dropout in those students who have hearing problems. The solution to this dropout is the awareness of the entire educational community in all educational fields, for this purpose informative talks, brochures and posters with information on the rights of deaf people have been proposed. In addition, this information has been taken to the digital spaces of social networks, so that it reaches the youngest part of society.

Sign language is a subject that should be present in all schools, both in the classrooms that require it and in activities and training that are done outside of class, such as free time in schools (time for recreation), outdoor activities, informative talks, etc. As the Federación Mundial de Personas Sordas (2019), In order to implement this language, it is necessary the previous training of the professors and of the professors of all the areas, since it should be a right that the students can access whenever they want or need it, it is also a learning that It promotes peer-to-peer communication, regardless of whether the participants in the conversation are people with hearing impairment. In addition to schools, they affirm that it should be an obligation to learn sign language to use it in all professions, since mastery of this language is necessary to gradually improve social inclusion.

Regarding the influence of the auditory deficit in the learning style and in the processing of the information of students with auditory functional diversity, these characteristics are determined in part by the main channel of perception of reality; the view, since as stated by different authors, including Fernández and Petursa (1996), The oral language is presented as a concatenation of sounds that by their nature are consecutive, that is, we cannot pronounce two words at the same time and therefore 
it is linear; However, sign language is simultaneous, allowing the superposition of ideas thanks to the single-manual and bi-manual signs with the different points of articulation, movement and contact, which together with facial expression can offer different complete meanings.

To solve the problems in schools regarding people with hearing problems, the Federación Mundial de Personas Sordas (2019) It demands a bilingual education of students, as well as the implementation of an education adapted to all the different needs of students with hearing impairment. Currently, this bilingual education already exists, but it needs full implementation in all educational centers. There are numerous problems for the creation of a bilingual education, such as inadequate informed learning standards, scarce teachers and teachers specifically trained and therefore few training programs for teachers.

In his study of deaf people in the classrooms of both Portugal and Turkey, Llorent (2010) explains that deaf people are a matter of concern for the whole society, but they really do not receive all the support they need it. With regard to sign language, it helps coexistence between equals, as well as the exchange of information between deaf and hearing people. In order to continue improving the coexistence between societies, it is necessary to facilitate the improvement of the quality of life of all people, especially people with hearing deficits, but it still requires a lot of effort in social and educational fields.

López-González (2010) highlights in his work, that society has yet to facilitate people with hearing problems, inclusion, since in many studies people with hearing deficits prefer to be in the same environment with other deaf people, for the communicative facility and its identification as people.

The importance of sign language communication is so important that Llorent (2010) bases that many professionals in schools, other than teachers, have been specifically trained in this language to be able to communicate directly with people with hearing difficulties. No need for interpreters. For this reason, it is currently preferred that the teaching staff of the schools be endowed with sign language knowledge since it facilitates intervention between families and schools, essential for deaf students.

In summary, without sign language there is no complete inclusion. Knowledge of this language is necessary for all areas of daily life, especially for the academic circle, prior training and knowledge is required. This training is of vital importance so that students with hearing disabilities feel equal with their classmates. Appropriate methodologies implemented by the teacher will be of importance for the complete elimination of exclusion towards students with hearing impairments.

\section{3.-Conclusion.}

It is essential that new knowledge in neuroeducation reach the classroom through teacher training to ensure a quality education for all, favoring the creation of a more just and inclusive society

In relation to teacher training in sign language, it is known that there is a large population that forms the society with hearing impairment, which is why it is of vital 
importance a continuous training of teachers who serve deaf students, for greater communication in The teaching-learning process.

The structuring at the brain level of deaf people is different from that of hearing people, therefore, the teaching specialization in neuroeducation is of great relevance, but you have to start at the base, learn sign language.

In conclusion, the sign language training of the educational community is essential to favor the inclusion of deaf students in the school, taking care of the needs of these students and increasing the self-esteem of students.

\section{4.-References.}

Astorga, M.L. (2012). Neurodiversidad y razonamiento lógico. Revista Educación Inclusiva. 3(2), 99-111.

Federación Mundial de Personas Sordas, (2019). Faro del silencio. La revista de todas las personas sordas. 253, 18-21.

Fernández, M.P., Pertusa, E. (1996). Reflexiones sobre la escritura y la alfabetización de los niños sordos. Revista de logopedia, foniatría y audiología. 16(2), 79-85.

Flórez, J. (2016). Neurodiversidad, discapacidad e inteligencias múltiples. Revista Síndrome de Down. 33(2), 59-64.

Llorent, V.J., López-González, M. (2010). Los alumnos sordos en las aulas de Portugal y Turquía. Revista Atención educativa a la diversidad, 8(12), 111123.

Pastor, C.A., (2012). Aportaciones del Diseño Universal para el Aprendizaje y de los materiales digitales en el logro de una enseñanza accesible. Recuperado de https://diversidad.murciaeduca.es/publicaciones/dea2012/docs/calba.pdf

Pastor, C.A., Hípola, P.S., Serrano, J.M. Sánchez, del Río, A.Z. (2013). Pautas sobre el Diseño Universal para el Aprendizaje (DUA). Traducción al español, Versión, 2.0 Versión 2.0 Universidad Complutense de Madrid, octubre 2013

Pastor, C.A., Sánchez, J.M., Zubillaga, A. (2014). Diseño Universal para el aprendizaje (DUA). Recuperado de: https://www.educadua.es/doc/dua/dua_pautas intro_cv.pdf

Soro Camat, E., Basil, C., Rosell, C. (1 ${ }^{\text {a }}$ ed.) (2012). Pluridiscapacidad y contextos de intervención. Barcelona: Institut de Ciències de l'Educació. Universitat de Barcelona. 
Revista Internacional de Apoyo a la Inclusión, Logopedia, Sociedad y Multiculturalidad. Volumen 6, Número 1, enero 2020, ISSN: 2387-0907. DOI: https://doi.org/10.17561/riai.v6.n1.8

Villoria, E.D., Fuentes, S.S. (2015). Diseño universal para el aprendizaje como metodología docente para atender a la diversidad en la universidad. Aula abierta, 43(2), 87-93. 